\title{
Studies on Japonica Hybrid Rice Seed Production under Egyptian Conditions
}

\author{
Selim, M. E.; H. Sh. Hamad; M. A. A. El Sayed and E. A. Z. El Shamey \\ Rice Research Department, Field Crops Research Institute, Agricultural Research Center, Egypt. \\ Corresponding author: hassanshehata28@yahoo.com
}

\begin{abstract}
Two- experiments were conducted at Sakha Experimental Farm of Sakha Agricultural Research station, Kaferelsheikh, Egypt during 2016 and 2017 rice growing seasons. The objective of this investigation was to study the effect of three Male(P):Female(S) rows ratio (2P:6S, 2P:8S and 2P:10S) and two pollen directions of the pollen parental line $(\mathrm{P})$, one direction and two directions on out-crossing rate for Japonica hybrid rice seed production. Japonica hybrid produce through crossed between one Thermo-sensitive Genic Male Sterile (TGMS) line (TG-60-6) as a female line (S) with Sakha105 which used as a male pollinator line (P). A split-plot design with three replications was used. The main plots were dedicated to rows ratio whereas direction of the pollen parental line was arranged within the sub plots. The results notify that the better row ratio was $2 \mathrm{P}: 6 \mathrm{~S}$ gave the best seed yield hill-1 (25.00 and 27.38 g) in 2016 and 2017 seasons respectively. For direction of the pollen parental line, the best $\mathrm{F}_{1}$ seed yield hill ${ }^{-1}$ (25.89 and $27.45 \mathrm{~g}$ ) were obtained once planted the spore parental line in two directions during 2016 and 2017 seasons, respectively. The interaction between row ratio and direction of the pollen parental line was highly significant for panicle weight $(\mathrm{g})$, seed set $(\%)$, number of fertile panicles hill-1, harvest index $(\%)$, and seed yield hill-1, but not significant for plant height $(\mathrm{cm})$ and panicle length $(\mathrm{cm})$ during 2016 and 2017 seasons. The results notify the importance of optimum row ratio and direction planted of pollen parental line for increasing the out-crossing rate in Japonica hybrid seed
\end{abstract}

Key words: Japonica hybrid rice (Oryza sativa L.), TGMS, Row ratio, Direction of pollen parental line, seed yield.

\section{Introduction}

Hybrid rice is the commercial rice seed which produced from a cross between two genetically dissimilar parental lines and grow as $\mathrm{F}_{1}$ seed. Threeline hybrids have the potential of yielding 15-20\% more than the best inbred variety grown under similar conditions (Virmani et al, 1997). In 1995, Yuan Long Ping declared utilization of two-line hybrid rice has basically succeeded since then many new two line hybrid combinations have been developed, released and used on large scale commercial production in china. Two-line hybrid rice generally has $5-10 \%$ yield advantage over the three-line hybrid rice combinations (Jiming and Long Ping, 2007). Produce of Japonica hybrid rice depend on Environmental Genic Male Sterility (EGMS) phenomenon. The EGMS is composed of two major types; Photo-sensitive Genic Male Sterility (PGMS) which is responsive to variations in day length, and Thermo-Sensitive Genic Male Sterility (TGMS) which is caused by temperature. A Fertility/Sterility Alternation of TGMS line is induced mainly by temperature. The existing TGMS lines become completely male sterile under higher temperature. TGMS trait is governed by major genes, thus enabling their easy transfer to any genetic background, no need for restorer genes in the male parents of two-line hybrids, this system is ideal for developing Japonica hybrids because most Japonica lines doesn't possess restorer genes (Mou-Tong et al., 2003).
The discovery of Environmental Genic Male Sterility (EGMS) was help rice breeder to produce of simple two-line Japonica hybrid rice. Compared with the three-line system, the two-line system (EGMS) has many advantages such as no need to a maintainer line for seed multiplication, thus making seed production simpler and more cost-effective. Maintaining grain self-sufficiency in Egypt has become hard mission for most reasons such as the population grows, water shortage and arable land shrinks, so the pressure on Egyptian food security is severe increasing. In general, there are two ways to increase the grain yield output of rice; expanding planting areas and increasing grain yield per unit area. However, expanding the planting area for rice in Egypt is not available due to water restrictions and strong competition from other crops. Therefore, the only one way to increase rice production is increasing rice grain yield. We can increase rice grain yield from unit area through produce high yield Japonica hybrids coupled with good grain quality (Zaman et al., 2002) that is minor goal from this investigation, and then increase the income of Egyptian farmers and the improvement of the Egyptian economy, which is the major goal from this study.

\section{Material and Methods}

The experimental materials were include one Thermo-sensitive Genic Male Sterile (TGMS) line (TG-60-6) developed in Egypt which was used as female line (S) and Sakha105 as pollen parent (P). The 
female TGMS line TG-60-6 was produced from hybridization between one reverse Thermo-sensitive Genic Male Sterile Line M.J5460s (china) with Sakha106 (Egypt) followed by pedigree selection methods in segregation generation from $F_{2}$ to $F_{6}$ into stability. This line was evaluated under different sowing dates to select best sowing date to induce complete sterility which used to produce Japonica hybrid rice in seed production program. Experimental materials, parentage origin and grain type were shown in Table 1.

Table 1. Rice parental lines, parentage origin and grain type

\begin{tabular}{ccccc}
\hline No. & Entries & Parentage & Origin & Grain type \\
\hline $\mathbf{1}$ & TG-60-6 & (M.J5460 S x Sakha106) & Egypt & Japonica \\
$\mathbf{2}$ & Sakha105 & (GZ 5581 x GZ 4316) & Egypt & Japonica \\
\hline
\end{tabular}

A split-plot design in RCBD arrangements with three replications was used. The main plots were devoted to the pollen parental line $(\mathrm{P})$ to the TGMS line $(\mathrm{S})$ row ratio $(2 \mathrm{P}: 6 \mathrm{~S}, 2 \mathrm{P}: 8 \mathrm{~S}$ and $2 \mathrm{P}: 10 \mathrm{~S})$ and direction of pollen parental line (one direction and two direction) were arranged in the sub plots with size 12.5 $\mathrm{m}^{2}(2.5 \times 5 \mathrm{~m})$ for each sub plot. The experiment border and each sub plot were isolated by a 2.5 meter height plastic insulation such are shown in figure 1.

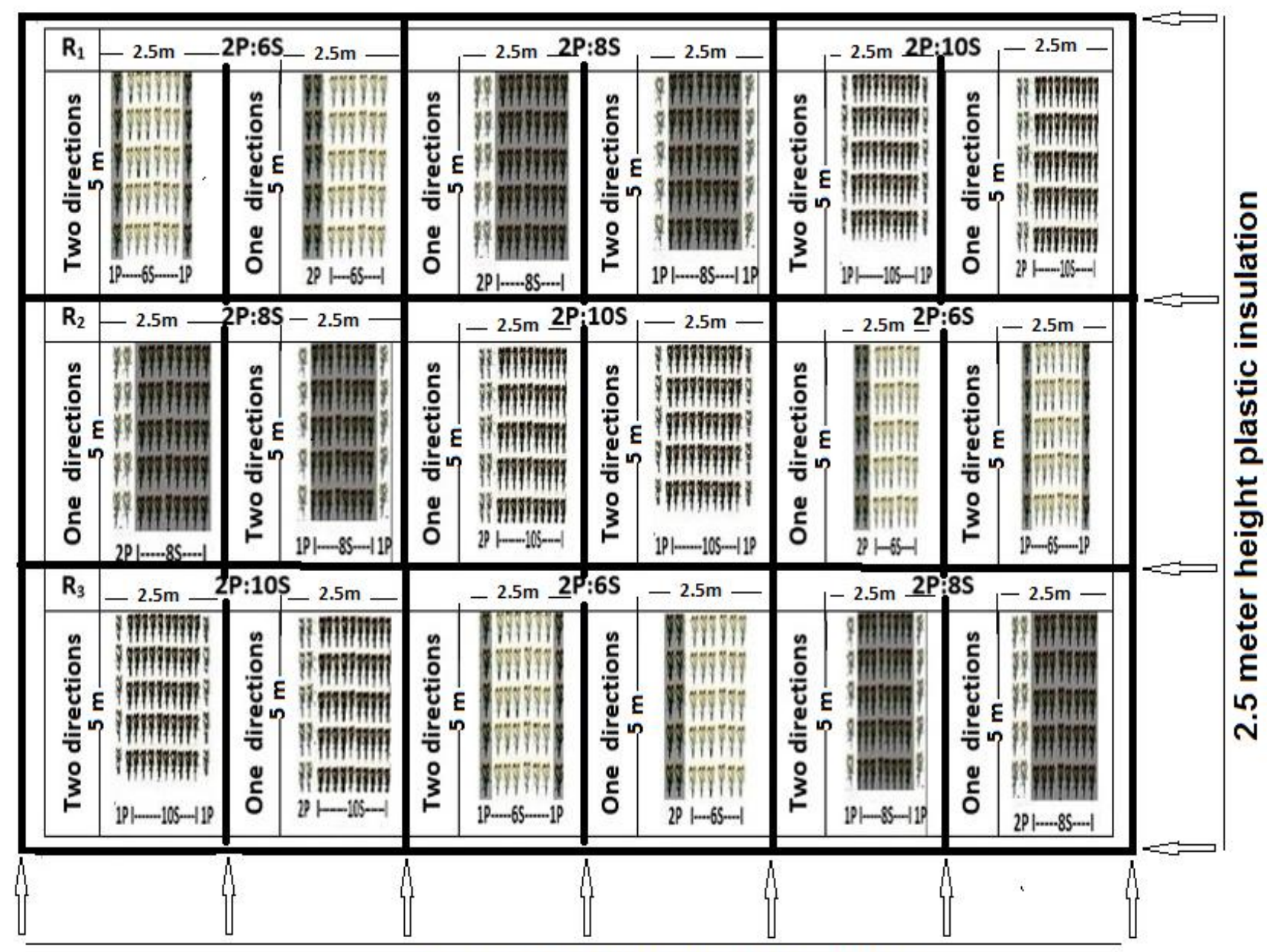

\section{5 meter height plastic insulation}

Spacing: between pollen parental line 'P' rows: $30 \mathrm{~cm}$, between TGMS line 'S' rows: $15 \mathrm{~cm}$, between 'P' \& 'S' line blocks: $20-30 \mathrm{~cm}$ and between hills ('S' \& 'P' lines): $15 \mathrm{~cm}$

Fig. 1 Design and arrangement of experiment, P-S row ratio and $\mathrm{P}$ transplanted directions.

Thermo-sensitive Genic Male Sterile (TGMS) line (TG-60-6) sown on May $3^{\text {rd }}$ and pollen parent Sakha 105 was sown at three different sowing date (April $22^{\text {th }}$, April $25^{\text {th }}$ and April $28^{\text {th }}$ ) to get a proper synchronization of flowering depend on days from planted to start flowering for both parental female and male lines. (TGMS) line (TG-60-6) earlier six days than pollen parent Sakha 105 which were 90 and 96 
days for TG-60-6 and Sakha105, respectively. TG-606 was start flowering at August $2^{\text {nd }}$ and continuous receipt pollen during $7^{\text {th }}$ days. While, every sowing date form Sakha105 as pollen parental line supply the female line with pollen grain during 5 days as shown in Figure 2.

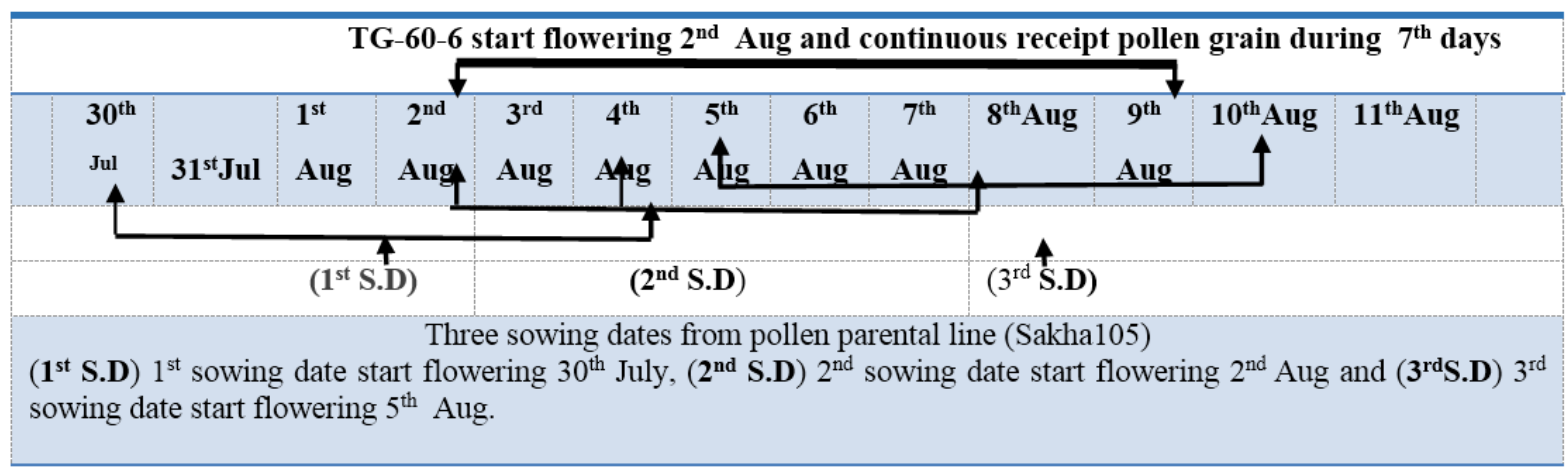

Fig. 2 flowering synchronization depends on days to flowering for parental lines TG-60-6 and Sakha105.

Days old seedlings of both $\mathrm{P}$ and $\mathrm{S}$ lines were transplanted by 3-4 and 2 seedlings per hill, respectively. The row spacing maintained for P-P, P$\mathrm{S}$, and $\mathrm{S}-\mathrm{S}$ lines were 20,30 , and $15 \mathrm{~cm}$, respectively. Hill spacing for both $\mathrm{P}$ and $\mathrm{S}$ lines were maintained at $15 \mathrm{~cm}$. Experiment grown under Isolation for hybrid seed production. Rice seeds at the seeding rate of 20 $\mathrm{kg} / \mathrm{ha}$ (15 kg from TGMS line (TG-60-6) and $5 \mathrm{Kg}$ from the parental line Sakha105 were soaked in a fresh water for 24 hours, then drained and incubated for 48 hours to hasten early germination.

The nursery seedbed was well ploughed and dry leveled. Phosphorous fertilizer was added in the form of single super phosphate $\left(15.5 \% \mathrm{P}_{2} \mathrm{O}_{5}\right)$ at the rate of $240 \mathrm{~kg} / \mathrm{ha}$ before tillage. Nitrogen in the form of urea $(46 \% \mathrm{~N})$ at the rate of $145 \mathrm{~kg} / \mathrm{ha}$ was added at the rate of $(95 \mathrm{~kg} / \mathrm{ha}$ as basal dressing, and the second 50 $\mathrm{kg} / \mathrm{ha}$ at panicle initiation. Zinc sulphate $22 \% \mathrm{ZnSO}_{4}$ at the rate of $50 \mathrm{~kg} / \mathrm{ha}$ was added after puddling and before planting. Data were collected for; plant height $(\mathrm{cm})$, panicle length $(\mathrm{cm})$, No of fertile panicles/hill, panicle weight $(\mathrm{g})$, seed set $(\%)$, harvest index $(\%)$ and seed yield hill $^{-1}(\mathrm{~g})$. The crop was harvested when 80 $\%$ of the grains became golden yellow in color. Grains were sun dried and adjusted at $14 \%$ moisture content to estimate grain yield.

Harvest index (HI \%) percentage was estimated according to the following formula:

Harvest index $(\mathrm{HI} \%)=\frac{\text { Grain yield (economic yield) }}{\text { Biological yield }} \times 100$

Seed set percentage was calculated according to the following formula

The data were collected according to Standard Evaluation System of IRRI (2013) for all the studied characters. All cultural practices were practiced as recommended for hybrid rice seed production

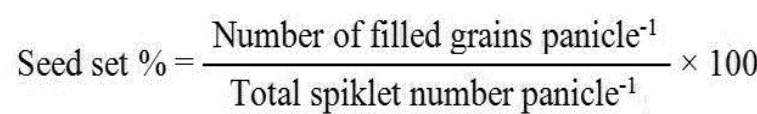
package. The data were analyzed following the ANOVA analysis and the mean differences were compared by the Duncan's Multiple Range Test Duncan (1956). Using a statistical computer package COSTAT (Gomez and Gomez, 1984).

Data of climate and weather conditions at the Farm of Sakha Agricultural Research Station, ARC, Egypt were recorded during two growing seasons 2016 and 2017 from $10^{\text {th }}$ May to $30^{\text {th }}$ Sep., Meteorological data regarding every ten days and the monthly means of wind velocity $\mathrm{km} / 24 \mathrm{hr}$., relative humidity (R.H. \%) and air temperature $\left({ }^{\circ} \mathrm{c}\right)$ are shown in Table 2 . Especially, air temperature data must be considered because it is important factor to induce sterility of female line (TG-60-6) as Thermo-sensitive Genic Male Sterility (TGMS). TGMS lines were complete sterility in air temperature more than $32{ }^{\circ} \mathrm{c}$ as maximum air temperature. Minimum of four continuous weeks with stable high temperature ( $>32 / 24^{\circ} \mathrm{c}$ day/night) for safe hybrid seed production.

Microscopic analysis for the TG-60-6 Line as female line and pollen parental line Sakha105. Pollen examination was made on five randomly plants from each replication to insure sterility in TG-60-6 and Sakha 105. Five spikelet's were collected from each main panicle and fixed in $70 \%$ alcohol. From these spikelet's 6 anthers were collected and smeared in iodine potassium iodide (IKI) solution (1\%) and examined under light microscope (40x10). All the unstained pollens were considered as sterile and the stained ones as fertile (Virmani et al, 1997). Bagging of five TG-60-6 plants from each sub plot by rate thirty plants from each replication and estimated seed set in these plants to judge in sterility of TG-60-6 line. 
Table 2 Climate and weather data during two growing seasons 2016 and 2017

\begin{tabular}{|l|c|c|c|c|c|c|c|c|c|c|}
\hline \multirow{2}{*}{ Date } & \multirow{2}{*}{$\begin{array}{l}\text { Wind Velocity } \\
\text { km/24 hr }\end{array}$} & \multicolumn{4}{c}{1.30 PM } & \multicolumn{3}{c}{7.30 AM } & \multicolumn{3}{c|}{ Mir Temperature } \\
\cline { 2 - 12 } & 2016 & 2017 & 2016 & 2017 & 2016 & 2017 & 2016 & 2017 & 2016 & Max \\
\hline 10 May & 105.2 & 94.6 & 47.5 & 46.9 & 80.3 & 76 & 17.27 & 20.98 & 29.15 & 28.8 \\
\hline 20 May & 124.5 & 96.2 & 44.6 & 41.5 & 79.2 & 65.6 & 18.38 & 24.36 & 30.32 & 32.53 \\
\hline 30 May & 114.00 & 100.1 & 46.30 & 48.90 & 72.50 & 71.4 & 20.71 & 22.93 & 31.10 & 29.72 \\
\hline Mean & 114.60 & 97.00 & 46.10 & 45.80 & 77.30 & 71.00 & 18.79 & 22.81 & 30.19 & 30.40 \\
\hline 10 June & 99.30 & 91.20 & 50.60 & 43.50 & 79.10 & 67.30 & 20.19 & 26.70 & 30.03 & 33.40 \\
\hline 20 June & 103.90 & 130.40 & 52.30 & 44.30 & 80.20 & 76.00 & 22.05 & 25.50 & 31.45 & 33.10 \\
\hline 30 June & 113.30 & 116.80 & 50.70 & 52.10 & 77.00 & 83.90 & 21.98 & 26.80 & 31.09 & 34.20 \\
\hline Mean & 105.30 & 112.80 & 51.20 & 46.60 & 78.80 & 75.70 & 21.40 & 26.30 & 30.85 & 33.60 \\
\hline 10 July & 114.10 & 109.90 & 53.50 & 57.50 & 82.80 & 83.40 & 24.80 & 26.50 & 32.80 & 33.90 \\
\hline 20 July & 90.10 & 99.10 & 57.60 & 54.20 & 88.40 & 83.00 & 25.30 & 25.90 & 33.40 & 33.70 \\
\hline 30 July & 87.60 & 107.40 & 51.80 & 58.60 & 87.40 & 81.70 & 26.30 & 26.00 & 34.30 & 32.90 \\
\hline Mean & 97.30 & 105.50 & 54.30 & 56.80 & 85.20 & 82.70 & 25.46 & 26.13 & 33.00 & 33.70 \\
\hline 10 Aug. & 84.60 & 87.90 & 52.50 & 57.60 & 83.50 & 84.80 & 26.20 & 26.20 & 35.90 & 34.30 \\
\hline 20 Aug. & 93.20 & 93.00 & 51.60 & 56.80 & 81.60 & 83.10 & 25.50 & 26.30 & 35.50 & 33.00 \\
\hline 30 Aug. & 95.90 & 97.60 & 51.10 & 54.40 & 86.40 & 85.00 & 24.30 & 25.50 & 33.90 & 33.90 \\
\hline Mean & 91.20 & 92.80 & 51.70 & 56.30 & 83.80 & 84.30 & 25.00 & 26.00 & 35.10 & 33.60 \\
\hline 10 Sep. & 84.60 & 86.80 & 52.50 & 53.70 & 83.50 & 85.40 & 26.20 & 24.30 & 35.90 & 33.27 \\
\hline 20 Sep. & 93.20 & 94.20 & 51.60 & 51.30 & 81.60 & 82.60 & 25.50 & 24.93 & 35.50 & 33.42 \\
\hline 30 Sep. & 95.90 & 104.30 & 51.10 & 50.30 & 86.40 & 81.40 & 23.30 & 23.63 & 33.90 & 31.09 \\
\hline Mean & 91.20 & 95.10 & 51.70 & 51.80 & 83.80 & 83.10 & 25.00 & 24.30 & 35.10 & 32.60 \\
\hline
\end{tabular}

\section{Results and Discussion}

Above all, it is necessary to clarify important of spikelet's bagging and pollen examination to safe hybrid rice seed production. To be sure the seed set in the female line were hybrid seed and not resulted from self-pollination. Bagging of plants indicated that, no seed set $\%$ at bagging female line TG-60-6. Pollen examination revealed that, complete sterility for TG60-6 as female line comparing with complete fertility for Sakha105 as pollen parent line as shown in figure3.

Effect of pollen parent Sakha 105 of the female TGMS rows ratio and direction of the male parent as well as their interaction on plant height, panicle length, panicle weight and number of fertile panicles hill $^{-1}$ characters are given in (Table 3).

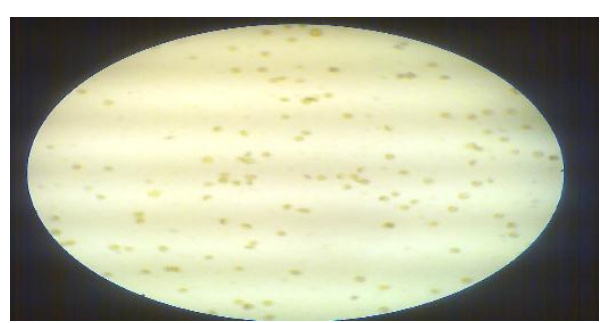

(b) Male sterility (TG-60-6)

Fig. 3 Show (a) male fertility pollen parental line (Sakha105), (b) male sterility female line (TG-60-6) as thermosensitive genic male sterility line for pollen examination.

\section{Pollen parental line to the TGMS row ratio effect}

The effect of the pollen parental line to TGMS row ratio was not significant for plant height and panicle length during 2016 and 2017 seasons. While, gave highly significant effect for panicle weight and number of fertile panicle hill ${ }^{-1}$, the parental line to TGMS ratio $2 \mathrm{P}: 6 \mathrm{~S}$ produced the heaviest panicles (1.82 and $2.02 \mathrm{~g})$ and (16.54 and 17.03 /hill) for fertile panicles hill ${ }^{-1}$ during both seasons, respectively. By contrast, the male parent Sakha 105 to TGMS row ratio $2 \mathrm{P}: 10 \mathrm{~S}$ produced the lowest panicles (1.58 and
$1.67 \mathrm{~g})$ and (14.97 and 14.90) for fertile panicles hill ${ }^{-1}$ in 2016 and 2017 seasons, respectively. Rahman $\boldsymbol{e t}$ al (2010) studied the effect of row ratio of restorer (R) and Cytoplasmic Male Sterility (A) lines on seed production of hybrid rice. Similar results were also found by Singh and Singh (1998).

\section{Direction of the pollen parental line effect}

Direction of the pollen parent Sakha 105 was not significant for the characters, plant height and panicle length. While, was highly significant effect for 
panicle weight and fertile panicles hill ${ }^{-1}$ as shown in Table 3. Two direction parent Sakha 105 produced the heaviest panicles (1.93 and $2.05 \mathrm{~g})$ and (16.09 and 16.87) for fertile panicles hill ${ }^{-1}$ during 2016 and 2017 seasons, respectively. On the other hand, one rows direction of pollen parent Sakha 105 produced the least panicle weight (1.84 and $1.60 \mathrm{~g}$ ) and gave (15.29 and $14.95 \mathrm{hill}^{-1}$ ) for fertile panicles hill ${ }^{-1}$ in 2016 and 2017 seasons, respectively. The results are in agreement with those reported by Huang et al (1998) and Zhu et al (1998).

\section{Interaction effect}

The interaction between pollen parent Sakha 105 for TGMS rows ratio and direction of pollen parent Sakha 105 has highly significant for panicle weight and fertile panicles hill ${ }^{-1}$ in 2016 and 2017 seasons, respectively. While, was not significant for the characters of plant height and panicle length in both seasons.

Table 3. Effect of pollen parental line to TGMS row ratio and direction of the pollen parental line, as well as, their interaction on plant characteristics during 2016 and 2017 seasons

\begin{tabular}{|c|c|c|c|c|c|c|c|c|}
\hline \multirow{2}{*}{$\begin{array}{l}\text { Main effect and } \\
\text { interaction }\end{array}$} & \multicolumn{2}{|c|}{ Plant height (cm) } & \multicolumn{2}{|c|}{$\begin{array}{c}\text { Panicle length } \\
(\mathrm{cm})\end{array}$} & \multicolumn{2}{|c|}{ Panicle weight (g) } & \multicolumn{2}{|c|}{$\begin{array}{c}\text { Number of } \\
\text { panicles/hill }\end{array}$} \\
\hline & 2016 & 2017 & 2016 & 2017 & 2016 & 2017 & 2016 & 2017 \\
\hline \multicolumn{9}{|l|}{ Row ratio } \\
\hline 2P:6S & 80.92 & 84.64 & 15.02 & 101.8 & $1.82 \mathrm{a}$ & $2.02 \mathrm{a}$ & $16.54 \mathrm{a}$ & $17.03 \mathrm{a}$ \\
\hline 2P:8S & 80.87 & 84.42 & 14.76 & 98.12 & $1.73 b$ & $1.78 \mathrm{~b}$ & $15.56 \mathrm{~b}$ & $15.80 \mathrm{~b}$ \\
\hline 2P:10S & 80.86 & 84.66 & 14.58 & 94.28 & $1.58 \mathrm{c}$ & $1.67 \mathrm{c}$ & $14.97 \mathrm{c}$ & $14.90 \mathrm{c}$ \\
\hline F-Test & NS & NS & NS & NS & $* *$ & $* *$ & $* *$ & $* *$ \\
\hline \multicolumn{9}{|l|}{ Direction } \\
\hline One Direction & 80.78 & 84.61 & 14.94 & 14.65 & $1.84 b$ & $1.60 \mathrm{~b}$ & $15.29 \mathrm{~b}$ & $14.95 b$ \\
\hline Two Direction & 80.99 & 84.53 & 14.64 & 14.62 & $1.93 \mathrm{a}$ & $2.05 \mathrm{a}$ & $16.09 \mathrm{a}$ & $16.87 \mathrm{a}$ \\
\hline F-Test & NS & NS & NS & NS & $* *$ & $* *$ & $* *$ & $* *$ \\
\hline $\begin{array}{l}\text { Interaction ( } \mathrm{R} x \\
\text { D) }\end{array}$ & NS & NS & NS & NS & $* *$ & $* *$ & $* *$ & $* *$ \\
\hline
\end{tabular}

** Highly significant at the $1 \%$ level of probability, NS not significant

The results in Table 4 showed that the interaction between pollen parent Sakha 105 and TGMS rows ratio and direction of pollen parent Sakha 105 has highly significant effect on panicle weight and fertile panicles hill ${ }^{-1}$ in both seasons 2016 and 2017, respectively. The pollen parent with TGMS ratio 2P:6S and two direction of pollen parental Sakha 105 gave the highest values of 2.15 and $2.22 \mathrm{~g}$ for panicle weight and gave 17.90 and 17.80 for fertile panicles hill $^{-1}$ in 2016 and 2017 seasons, respectively. While, male parent Sakha 105 with TGMS rows ratio 2P:10S with one direction parent lines produced the lowest values of 1.40 and $1.47 \mathrm{~g}$ for panicle weight and (14.87 and 14.00/hill) for number of fertile panicles/hill during both seasons, respectively. Similar results were also found by Prabagaran and Ponnuswamy (1997) and Kumar and Nautiyal (2016).

Table 4. Effect of interaction between parental line to TGMS ratio and direction parent lines on panicle characteristics during 2016 and 2017 seasons

\begin{tabular}{|c|c|c|c|c|c|}
\hline \multirow{2}{*}{ Direction } & \multirow{2}{*}{ Row ratio } & \multicolumn{2}{|c|}{ Panicle weight (g) } & \multicolumn{2}{|c|}{ Number of panicles /hil } \\
\hline & & 2016 & 2017 & 2016 & 2017 \\
\hline \multirow{3}{*}{ One Direction } & $2 \mathrm{P}: 6 \mathrm{~S}$ & $\begin{array}{ll}1.57 d & 1.49\end{array}$ & $1.82 \mathrm{c}$ & $15.90 \mathrm{c}$ & $16.25 \mathrm{c}$ \\
\hline & $2 \mathrm{P}: 8 \mathrm{~S}$ & $\mathrm{e}$ & $1.52 \mathrm{e}$ & $15.1 \mathrm{~d}$ & $14.60 \mathrm{~d}$ \\
\hline & $2 \mathrm{P}: 10 \mathrm{~S}$ & $1.40 \mathrm{f}$ & $1.47 \mathrm{f}$ & $14.87 \mathrm{f}$ & $14.00 \mathrm{f}$ \\
\hline \multirow{3}{*}{ Two Direction } & $2 \mathrm{P}: 6 \mathrm{~S}$ & $2.15 \mathrm{a}$ & $2.22 \mathrm{a}$ & $17.90 \mathrm{a}$ & $17.80 \mathrm{a}$ \\
\hline & $2 \mathrm{P}: 8 \mathrm{~S}$ & $1.89 \mathrm{~b}$ & $2.10 \mathrm{~b}$ & $16.02 b$ & $17.01 \mathrm{~b}$ \\
\hline & 2P:10S & $1.77 \mathrm{c}$ & $1.82 \mathrm{~d}$ & $15.07 \mathrm{e}$ & $15.80 \mathrm{e}$ \\
\hline
\end{tabular}

\section{Pollen Parent Sakha 105 with TGMS line rows ratio effect}

The effect of Parent Sakha 105 to TGMS ratio has highly significant effect on the characters of seed set percentage, harvest index and seed yield were showed in table 5. The pollen parental line to TGMS rows ratio 2P:6S gave the highest values of 27.85 and $28.67 \%$ for seed set, $(16.58$ and $17.58 \%)$ for harvest index and ( 25.89 and $27.45 \mathrm{~g} /$ plant) for seed yield in during 2016 and 2017 seasons, respectively. But, the Parental line to TGMS row ratio $2 \mathrm{P}: 10 \mathrm{~S}$ produced the lowest values (23.86 and $24.68 \%$ ) for seed set, (14.08 and $14.53 \%$ ) for harvest index and (19.92 and $21.32 \mathrm{~g}$ ) for seed yield plant $^{-1}$ in the first and second seasons, respectively. The results are in agreement with those reported by Abo-Youssef, (2009), Viraktamath and Ramesha (1996). 


\section{Direction of pollen parent Sakha 105 effect}

Direction of male parental line has highly significant effect on seed set, harvest index and seed yield. Two directions produced the highest values (28.77 and $29.22 \%$ ) for seed set, (16.55 and $17.93 \%$ ) for harvest index and (25.89 and $27.45 \mathrm{~g})$ for seed yield hill-1 in 2016 and 2017 seasons, respectively. By contrast, one direction gave the lowest values (23.04 and $24.27 \%$ ) for seed set, (13.83 and $14.17 \%$ ) for harvest index and (18.83 and $21.06 \mathrm{~g}$ ) for seed yield plant $^{-1}$ in 2016 and 2017 seasons, respectively. Similar results were also found by El-Mowafi $\boldsymbol{e t}$ al (2016) and Virmani (2003).

Table 5. Effect of Parental line to TGMS ratio and direction parental line, as well as, their interaction on seed set, harvest index and seed yield during 2016 and 2017 seasons

\begin{tabular}{|c|c|c|c|c|c|c|}
\hline \multirow{2}{*}{$\begin{array}{l}\text { Main effect and } \\
\text { interaction }\end{array}$} & \multicolumn{2}{|c|}{ Seed set $(\%)$} & \multicolumn{2}{|c|}{ Harvest index $(\%)$} & \multicolumn{2}{|c|}{ Seed yield hill $^{-1}(\mathrm{~g})$} \\
\hline & 2016 & 2017 & 2016 & 2017 & 2016 & 2017 \\
\hline \multicolumn{7}{|l|}{ Row ratio } \\
\hline 2P:6S & $27.85 \mathrm{a}$ & $28.67 \mathrm{a}$ & $16.58 \mathrm{a}$ & $17.58 \mathrm{a}$ & $25.00 \mathrm{a}$ & $27.38 \mathrm{a}$ \\
\hline 2P:8S & $26.03 b$ & $26.89 b$ & $14.91 \mathrm{~b}$ & $16.04 \mathrm{~b}$ & $22.16 b$ & $24.07 \mathrm{~b}$ \\
\hline 2P:10S & $23.86 \mathrm{c}$ & $24.68 \mathrm{c}$ & $14.08 \mathrm{c}$ & $14.53 \mathrm{c}$ & $19.92 \mathrm{c}$ & $21.32 \mathrm{c}$ \\
\hline F-Test & $* *$ & $* *$ & $* *$ & $* *$ & $* *$ & $* *$ \\
\hline \multicolumn{7}{|l|}{ Direction } \\
\hline One Direction & $23.04 b$ & $24.27 \mathrm{~b}$ & $13.83 b$ & $14.17 b$ & $18.83 b$ & $21.06 \mathrm{~b}$ \\
\hline Two Direction & $28.77 \mathrm{a}$ & $29.22 \mathrm{a}$ & $16.55 \mathrm{a}$ & $17.93 \mathrm{a}$ & $25.89 \mathrm{a}$ & $27.45 a$ \\
\hline F-Test & $* *$ & $* *$ & $* *$ & $* *$ & $* *$ & ** \\
\hline Interaction ( $\mathbf{R} \times \mathbf{D})$ & $* *$ & $* *$ & $* *$ & $* *$ & $* *$ & $* *$ \\
\hline
\end{tabular}

** Highly significant at the $1 \%$ level of probability.

\section{Interaction effect}

The interaction between pollen parent Sakha 105 to TGMS rows ratio and direction of the parental line was highly significant for seed set, harvest index and seed yield during 2016 and 2017 seasons, respectively. The results in Table 6 showed that the interaction between pollen parental line to the TGMS row ratio and direction of pollen parental line has highly significant effect on seed set, harvest index and seed yield in both seasons. The pollen parent line to TGMS row ratio $2 \mathrm{P}: 6 \mathrm{~S}$ with two direction pollen parental line gave the highest values (30.50 and 31.04 $\%$ ) for seed set \%, (18.26 and $20.03 \%)$ for harvest index and (29.47 and $30.16 \mathrm{~g} / \mathrm{plant})$ for seed yield in 2016 and 2017 seasons, respectively. While, pollen parent to TGMS rows ratio $2 \mathrm{P}: 10 \mathrm{~S}$ with one direction pollen parent produced the lowest values (20.17 and $22.02 \%)$ for seed set, (13.05 and $13.22 \%)$ for harvest index and (16.77 and $17.54 \mathrm{~g} / \mathrm{plant})$ for seed yield during both seasons, respectively. Similar results were obtained by Jia et al (2001).

Table 6. Effect of interaction between pollen parental line to TGMS row ratio and direction of pollen parent lines on seed set, harvest index and seed yield during 2016 and 2017 seasons

\begin{tabular}{cccccccc}
\hline \multirow{2}{*}{ Direction } & \multirow{2}{*}{ Row ratio } & \multicolumn{2}{c}{ Seed set $(\boldsymbol{\%})$} & \multicolumn{2}{c}{ Harvest index $(\boldsymbol{\%})$} & \multicolumn{2}{c}{ Seed yield hill $\boldsymbol{1}^{\mathbf{1}}(\mathbf{g})$} \\
\cline { 3 - 7 } & & 2016 & 2017 & 2016 & 2017 & 2016 & 2017 \\
\hline \multirow{3}{*}{ One Direction } & $2 \mathrm{P}: 6 \mathrm{~S}$ & $25.20 \mathrm{~d}$ & $26.30 \mathrm{~d}$ & $14.90 \mathrm{~d}$ & $15.13 \mathrm{~d}$ & $20.53 \mathrm{~d}$ & $24.60 \mathrm{~d}$ \\
& $2 \mathrm{P}: 8 \mathrm{~S}$ & $23.19 \mathrm{e}$ & $24.5 \mathrm{e}$ & $13.57 \mathrm{e}$ & $14.17 \mathrm{e}$ & $19.17 \mathrm{e}$ & $21.06 \mathrm{e}$ \\
& $2 \mathrm{P}: 10 \mathrm{~S}$ & $20.17 \mathrm{f}$ & $22.02 \mathrm{f}$ & $13.02 \mathrm{f}$ & $13.22 \mathrm{f}$ & $16.77 \mathrm{f}$ & $17.54 \mathrm{f}$ \\
\hline \multirow{3}{*}{ Two Direction } & $2 \mathrm{P}: 6 \mathrm{~S}$ & $30.5 \mathrm{a}$ & $31.04 \mathrm{a}$ & $18.26 \mathrm{a}$ & $20.03 \mathrm{a}$ & $29.47 \mathrm{a}$ & $30.16 \mathrm{a}$ \\
& $2 \mathrm{P}: 8 \mathrm{~S}$ & $28.81 \mathrm{~b}$ & $29.30 \mathrm{~b}$ & $16.26 \mathrm{~b}$ & $17.91 \mathrm{~b}$ & $25.15 \mathrm{~b}$ & $27.09 \mathrm{~b}$ \\
& $2 \mathrm{P}: 10 \mathrm{~S}$ & $27.02 \mathrm{c}$ & $27.33 \mathrm{c}$ & $15.14 \mathrm{c}$ & $15.84 \mathrm{c}$ & $23.07 \mathrm{c}$ & $25.08 \mathrm{c}$ \\
\hline
\end{tabular}

\section{References}

Abo-Youssef, M. I (2009). The optimum row ratio and doses of $\mathrm{GA}_{3}$ for two rice CMS lines multiplication. Proc. of $6^{\text {th }}$ International Plant Breeding Conference, Ismailia, Egypt: 326-338.

Duncan, B. D. (1956). Multiple range and multiple F. test. Biometrics, 11: 42 -1.

El-Mowafi, H. F., A. A. El Gammaal, E. F. A. Arafat and W. A. A. Abd Elrahman (2016). Studies on hybrid rice seed production for Egytian cytoplasmic genetic male sterile line Sakha 1A/B multiplication, J. Agric. Res. Kafr El-Sheikh Univ. A. Plant production 42(3).

Gomez, K. A and A. A. Gomez (1984). Statistical Procedures for Agricultural Research. 2nd Ed. John Wiley and Sons, Inc. New York, USA.

Huang, P., K. Maruyania, H. L. Sharma and S. S. Virmani (1998). Advances in hybrid rice seed production technology. New developments and prospects, IRRI. : 67-70. 
IRRI (2013). Standard Evaluation System for Rice, $35^{\text {th }}$ ed International Rice Testing Program.

Jia, J.H., D.S. Zhang, C.Y. Li, X. P. Qu and S.W. Wang (2001). Molecular mapping of the reverse thermo-sensitive genic male sterile gene (rtms1) in rice. Theor. Appl. Genet., 103, 607-612.

Jiming, P. and Y. Longping (2007). Methodology for genetic purification of hybrid rice parents. International rice commission, Food and Agriculture Organization of the United Nations.

Kumar, $P$ and M. K. Nautiyal (2016). Two-Line Hybrid Production System and their Applications in Rice. International Journal of Agriculture Sciences, ISSN: 0975-3710 \& E-ISSN: 09759107, Volume 8, Issue 61, pp. 3502-3504.

Mou-Tong, M., Lu, X. G., Hoan, N. T. and Virmani, S. S. (2003). Two-line hybrid rice breeding in and outside China. Hybrid rice for food security, poverty alleviation and environmental protection Proceedings of the 4th International Symposium on Hybrid Rice, Hanoi, Vietnam, 31-52.

Prabagaran, S. R and A. S. Ponnuswamy (1997). Determination of ideal row ratio for hybrid rice seed production. Madras Agr. I. 84:230-231.

Rahman, M. H., M. H. Ali, M. J. Hasan, M. U. Kulsum and M. M. Khatun (2010). Out-crossing rate in row ratio of restorer and CMS lines for hybrid rice seed production. Eco-friendly Agril. J. 3(5): 233-236.
Singh, R and B. Singh (1998). Genetic variability in floral traits of 10 cytosterile lines of rice (Oryza sativa. L.). IRRI, Notes 23:3- 4.

Singh, S. K.; P. K. Bhati, S. Amita and S. Vikas (2015). Super hybrid rice in China and India: Current Status and Future Prospects. Int. J. Agric. Biol., 17: 221-232.

Viraktamath, B. V and M. S. Ramesha (1996). Synchronization, prediction and adjustment of flowering. Hybrid rice technology. Directorate of Rice Research compiled and edited by M. Ilyas Ahmed, B. C. Viraktamath, M. S. Ramesha, C. H. M. Vijaya Kumar PP 151; 77: 853.

Virmani, S. S.; B. C. Viraktamath; C. L. Casal ; R. S. Toleade; M. T. Lopez, and J. O. Manalo (1997). Hybrid rice Breeding Manual. 40-41.

Virmani, S. S (2003). Advances in hybrid rice research and development in the tropics. Hybrid rice for food security, Poverty Alleviation, and Environmental Protection. IRRI. P 7-20.

Zaman, F. U., A. O. Bastawisi, A. E. Draz, H. F. ElMowafy and M. I. Abo-Youssef (2002). Hybrid rice technology in Egypt present status and future strategies. FAO RRTC, I: 1-1 7 Zhej iang. Nongye Kexue, (3):129-130.

Zhu, Y. Y., X. H. Liang and L. Gao. (1998). The yield effect of spraying with water soluble $\mathrm{GA}_{3}$ in hybrid rice seed production. Zhejiang Nongye Kexue, No. 3. Pp. 129-130. 


$$
\begin{aligned}
& \text { دراسات على انتاج تقاوى الأرز الهجين اليابانى تحت الظروف المصرية }
\end{aligned}
$$

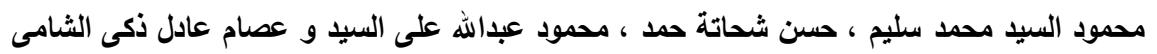

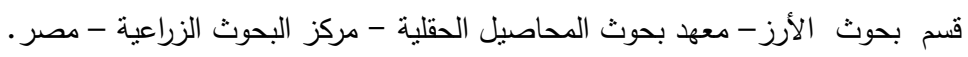

أجريت تجربة فى موسمي 2016 و 2017 بمزرعة محطة البحوث الزراعية بسخا- كفر الثيخ بهدف دراسة تأثير نسب سطور الأب للأم

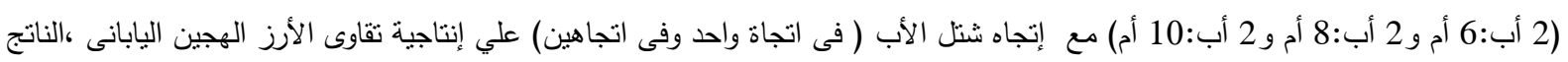

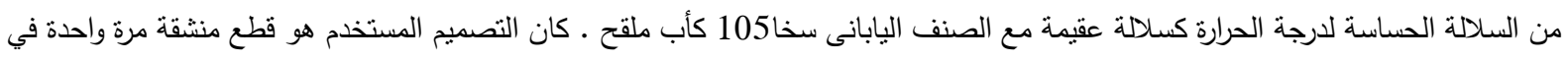

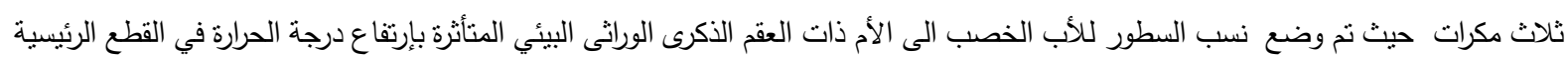

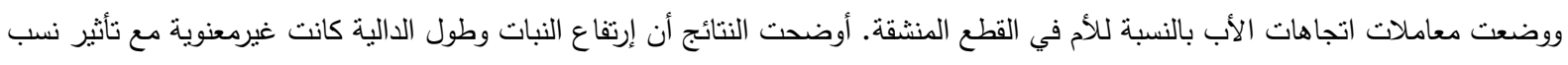

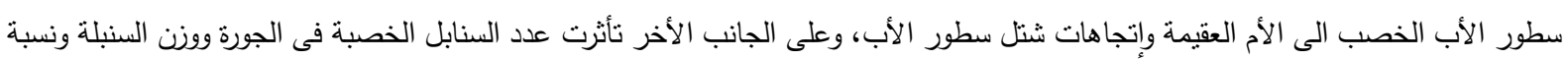

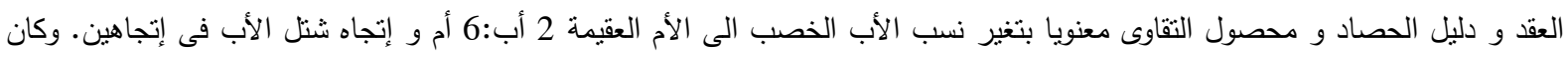

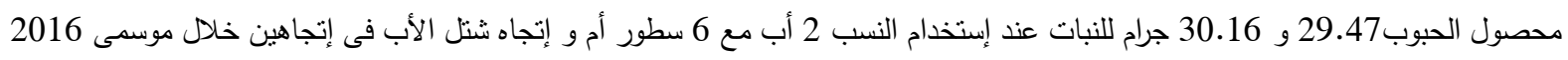
و2017. النتائج السابقة أعطت أهمية نسب الأب للأم المنلى وإتجاه شتل الأب لزيادة معدل التلقيح الخلطى فى حقل إنتاج تقاوى الأرز الهجين الهين 